\title{
Analysis of Dairy Farming Systems in the Sahelian Zone of Burkina Faso
}

Hadja Sanon ( $\nabla$ hadja_osanon@yahoo.fr )

INERA

NEYA Samuel

INERA: Institut de l'Environnement et de Recherches Agricoles

KONFE Salif

Université Nazi Boni

BOUGOUMA Valérie

Université Nazi Boni

\section{Research Article}

Keywords: Milk production, Feed supplementation, Crop residues, Cattle, Survey

Posted Date: November 10th, 2021

DOI: https://doi.org/10.21203/rs.3.rs-982946/v1

License: (c) (1) This work is licensed under a Creative Commons Attribution 4.0 International License. Read Full License 


\section{Abstract}

The insufficiency and variability of pasture production is a determining factor in milk production, particularly in the Sahelian zone. The objective of this study was to characterize dairy production systems and their relationship with crops to meet livestock needs. It consisted of surveys of 120 farmers in four communes in the Séno province. The results show three groups of dairy farmers that are essentially differentiated by the main activity and the sex of the farmers as well as the size of the cattle herd on the farm. The first group is made of male agropastoralists, with herds averaging 12 cattle. Group 2 consists of male agropastoralists with an average of 22 cattle. Group 3 consists of female pastoralists $(96.15 \%)$, with a herd size of about 19 head. The cows are fed on pasture and supplemented with crop residues with cotton cake, which is more important in group 2, where more farmers have hayloft for fodder conservation and manure pits compared to the other two groups. Crop residues are used primarily as feed in all groups from January to May. This supplementation allows the maintenance of milk production in the dry season and group 2, with more dairy cows, records more milk milked (6.5 and $3.8 \mathrm{I}$ ) and consumed in wet and dry seasons compared to the other two groups. The results suggest that the farmers in the area have low technical level and need capacity building in agropastoral fields to improve their production.

\section{Introduction}

In Burkina Faso, livestock activities involve nearly $87 \%$ of the active population and constitute the main insurance against risks for poor populations, whose livelihoods are based on rainfed agriculture (CSAOOCDE / CEDEAO, 2008). The animal population is large and diversified, with approximately 9 million cattle, 14 million goats, 9,3 million sheep and 44 million poultry (MRAH, 2015). This livestock allows the production of about 0.35 million tons of meat and 264000 tons of milk per year (FAO, 2019). However, this contribution is relatively low in relation to the sector's potential and could be explained by the low productivity of the animals, the low processing of products and the low marketing of raw products. In fact, Burkina Faso's livestock production is largely based on traditional extensive systems (87\%), which lead to low animal productivity.

The Sahelian region of Burkina Faso, is home to a large cattle population estimated at more than 2 million heads in 2018, which provides most of the milk produced. However, the environment marked by a high human population pressure, increasing urbanization, climate change and variability, leads to a more or less pronounced pauperization of the Sahelian populations. Thus, the transformation of agricultural production systems has emerged as a response to the deterioration in the purchasing power of the most vulnerable population. Indeed, several studies show that agricultural performance can be improved in a sustainable manner by developing synergies between crop and livestock production activities (Alary et al., 2011; Staal, 1995; Camara et al., 2015). In this dynamic of evolution of the agricultural systems, livestock and particularly milk production occupy a prominent place as a factor of poverty reduction and economic growth. Milk is one of the few speculations that allows a daily inflow of money, without damaging the system that produces it (Boukary et al., 2007). 
Thus, to face the growing demand for meat and milk in general, animal husbandry has a major role to play in food security policies, although its future will depend on the mechanisms of its spatial and temporal integration in agricultural areas, the forms of integration with other activities (fertility management, effect on the environment) and the insurance systems in the adaptation strategies to go beyond the stage of survival strategy (Alary et al., 2011).

The aim of this study was to characterize dairy farming systems and their relationship with crops in the Sahelian zone of Burkina Faso in order to identify avenues for improvement.

\section{Materials And Methods}

\section{Study area}

This study was conducted in the Sahel region of Burkina Faso, more specifically in the Séno province located between 13th and 14th degrees of the north latitude. This province is bordered at the north by the province of Oudalan, at the northwest by the province of Soum, at the south by the provinces of Namentenga, Gnagna and Gourma, and at the east by the Republic of Niger. This province is composed administratively of the urban commune of Dori and the rural communes of Bani, Falagountou, Gorgadji, Sampelga, and Seytenga (DREP/Sahel, 2014).

The study involved four sites including three rural communes that are: Bani, Gorgadji, and Seytenga and the village of M'Bamga belonging to Dori department (Figure 1).

\section{Methodology}

It has consisted in the elaboration of questionnaires to collect information related to:

- the socio-economic characteristics of farmers (identity, age, sex, socio-economic activities, household size, level of education, herd size);

- the means and strategies of animal production (type of habitat, management methods, health practices, supplementation practices);

- the relation between crop and livestock productions;

- the milk production.

These questionnaires were first tested with few farmers before the actual survey phase, which involved all four sites. The sampled population consisted of 120 farmers, with 30 farmers per site. The snowball sampling method was applied, starting with the target farmers (12 per site) who were asked to suggest other farmers to be included in the sample.

\section{Statistical analysis of the data}

- SPSS software was used to analyze the data. A hierarchical ascending classification was applied to the parameters on the main characteristic variables of the dairy production units. This resulted in 
three groups with a similarity level of $19.7 \%$. The Chi-square test was then used to compare the different groups of farmers, with a significance level of $5 \%$.

\section{Results}

\section{Farm typologies}

The result of the ascending hierarchical classification of observations allows to discriminate the farms into three groups (Figure 2). The main variables that had a significant effect on this distribution were gender, main activity, membership in a farmer organization (FO), beneficiary of support and training, herd size and the existence of a hayloft. The three groups are:

- Group 1, with 57 farmers (47.50\%), is composed mainly of male agropastoralists (98.25\%), the majority of whom are not affiliated to a FO and do not receive support, but all have received training (100\%);

- Group 2 comprises 37 farmers (30.83\%), all of whom are male agropastoralists (100\%), the majority are members of a FO (94.59\%) and receive support (94.59\%), but few have received training (40.54\%);

- Group 3 accounts 26 farmers (21.67\%), mainly female pastoralists (96.15\%), who have received training (88.46\%); half of them are affiliated with a FO (57.69\%) and have received support (50\%).

\section{General characteristics of farmers surveyed}

Table 1 shows the general characteristics of the three groups of farmers surveyed. The first two groups are made up mainly of men, while the third group is made up mainly of women. There is no significant difference between the three groups with respect to the age of the respondents or their level of education. We note that the group of age 30 to 50 years old, is more represented in all groups with $56.14,56.76$ and $61.54 \%$ of respondents respectively in groups 1, 2 and 3 . For the level of education, the majority of group 1 and 2 are illiterate (56 and 65\% respectively); however, group 3 has more educated respondents (58\%).

The main activity practiced differs significantly between the groups. The first two groups are agropastoralists, while group 3 consists mainly of women who practice livestock farming as their main activity. The proportion of farmers who are members of a FO and who receive support is significantly higher in group 2 (95\%). For the capacity building in dairy production techniques, farmers in groups 1 and 3 benefited the most $(p<0.001)$ from training $(100 \%$ and $84 \%$ respectively).

Table 1 : Socioeconomic characteristic of farmers surveyed (\%) 


\begin{tabular}{lllll} 
Parameters & Group 1 & Group 2 & Group 3 & P - value \\
\hline Sex & & & & \\
\hline - male & 98,25 & 100 & 03,85 & $* * *$ \\
\hline - female & 01,75 & 0 & 96,15 & \\
\hline Age (years) & & & & \\
\hline - less than 30 & 12,28 & 0 & 11,54 & ns \\
\hline - 30 to 50 & 56,14 & 56,76 & 61,54 & \\
\hline - more than 50 & 31,58 & 43,24 & 26,92 & \\
\hline Main activity & & & & \\
\hline - pastoral & 0 & 0 & 96,15 & $* * *$ \\
\hline - agropastoral & 100 & 100 & 03,85 & \\
\hline Level of instruction & & & & \\
\hline - illiterate & 56,14 & 64,86 & 34,61 & ns \\
\hline - literate & 10,53 & 21,62 & 07,69 & \\
\hline - educated & 33,33 & 13,51 & 57,69 & \\
\hline Member of farmer's organisation & 33,33 & 94,59 & 57,69 & $* * *$ \\
\hline Beneficiary of support & 22,81 & 94,59 & 50 & $* * *$ \\
\hline Beneficiary of training & 100 & 40,54 & 88,46 & $* * *$ \\
\hline
\end{tabular}

ns : not significant; $* * *: p<0,001$

\section{Characteristics of the cattle farms}

The characteristics of the farms are presented in Table 2. In the three groups, the herd size between 10 and 20 head of cattle dominates $(P<0.01)$ with $43.86 \%, 45.95 \%$ and $50 \%$ for group 1,2 and 3 respectively. The category of farmers with more than 40 head of cattle is only observed in groups $2(16.22 \%)$ and 3 (3.85\%). About $40 \%$ of the farmers in group 2 have herds of more than 20 cattle, while in group 1, the herd size of less than 10 heads, is important (43.86\%); thus, group 2 is considered to be the large farmers group and the herd size of 22 head is recorded, which is significantly different from herd size in group 1 (12 head), but not different from that of group 3 (19 head)

The production system is dominated by the extensive ones (>80\%) in the three groups of farmers. The animals, especially the dairy cows, are fed on pasture and supplemented with crop residues and sometimes cotton cake in the dry season. The techniques for distributing and processing roughage do not differ significantly between the three groups. More than half of the farmers in groups 1 and 3 (58\% 
and $54 \%$ respectively) process the roughage physically (chopping or cutting) before serving it to the animals. The supplementation with cottonseed cake is known in all groups, although the quantities are significantly higher in group 2 (44 bags).

For fodder conservation, very few farmers have a hayloft; this is observed only in group 2 with $24 \%$ of farmers and this proportion is significantly different from that of the other two groups. Most farmers store their fodder in various uncovered places.

Regarding the housing, we observe that the majority of farmers in all groups do not have any or use basic means to shelter their animals: pens made of thorny tree branches. Only about $4 \%$ of farmers in group 3 have a covered habitat.

Table 2: Characteristics of farms (\%)

ns : not significant ; $: p<0,05 ; * *: p<0,001$

\section{Crop residue management}

The main crops grown in the study area are cowpea, millet and sorghum by $98 \%, 97 \%$ and $93 \%$ of respondents respectively. Maize is also grown by $52 \%$ of respondents on small areas, and groundnuts by 40\% (Table 3).

- Types of crop residue use

Various types of use are made of the residues from these crops. Animal feeding ( $100 \%$ of respondents) is the main type of use in the households of the farmers surveyed; it is followed in descending order of importance by the production of potash ( $87 \%)$, use as fuel (58\%), construction of housing (28\%), and sale (28\%) of a part as fodder.

- Storage of crop residues

The devices used to store crop residues for use as livestock feed in the dry season, consist mainly of sheds (65\% of respondents). Other means are tree branches (48\%), fences made of thorny branches $(42 \%)$ and house roofs (34\%). A small proportion of respondents use a hayloft to store their fodder.

For the majority (90\%) of respondents, storage in the field (trees, fences with thorny branches) and distribution of fodder are done on site.

Table 3. Management of crop residues 


\section{Parameters}

Herd size (number of heads)

- less than 10

-10 to 20

-20 to 40

- more than 40

Average number of cattle

Production system

- extensive

- semi-intensive

Feeding method: pastures + supplements 100

fodder distribution technique

- in state

- cup

Amount of cottonseed cake (bags)

Existence of hayloft

Type of habitat

- enclosures

- none

- fencing

- covered habitat

Management of manure

Storage in piles

Storage in manure pit

Disposed in the field

\section{Group 1 Group 2 Group 3 P-value}

\begin{tabular}{llll}
43,86 & 13,51 & 19,23 & \\
433,86 & 45,95 & 50 & ** \\
\hline 12,28 & 24,32 & 26,92 & \\
\hline 0 & 16,22 & 03,85 & \\
11,91 & 22,19 & $18,96 \quad * \star \star$ \\
\hline
\end{tabular}

$89,47 \quad 81,08 \quad 80,77 \quad$ ns

$10,53 \quad 18,92 \quad 19,23$

$100 \quad 100 \quad$ ns

$42,11 \quad 56,76 \quad 46,15 \quad n s$

$57,89 \quad 43,24 \quad 53,85$

$20,90 \mathrm{a} \quad 44,44 \mathrm{~b} \quad 17,44 \mathrm{a} \quad$ **

$07,02 \quad 24,32 \quad 03,85$ *

$\begin{array}{llll}56,14 & 56,76 & 57,69 & \\ 42,11 & 40,54 & 38,46 & \text { ns } \\ 01,75 & 02,70 & 0 & \\ 0 & 0 & 03,85 & \end{array}$

$21,67 \quad 14,17 \quad 4,17$ *

$5 \quad 10 \quad 4,17$

$20,83 \quad 6,67 \quad 13,33$




\section{Proportions des producteurs (\%)}

\begin{tabular}{|c|c|c|}
\hline \multirow[t]{5}{*}{ Type of speculations } & Cowpea & 98 \\
\hline & Millet & 97 \\
\hline & Sorghum & 93 \\
\hline & Maize & 52 \\
\hline & Groundnut & 40 \\
\hline \multirow[t]{5}{*}{ Uses of crop residues } & Feeding & 100 \\
\hline & Construction of habitat & 28 \\
\hline & Potash production & 87 \\
\hline & Fuel (firewood) & 58 \\
\hline & Sale & 28 \\
\hline \multirow[t]{5}{*}{ Mode of storage } & Hayloft & 12 \\
\hline & Shed & 65 \\
\hline & Fence / thorny branches & 42 \\
\hline & House & 34 \\
\hline & Tree & 48 \\
\hline
\end{tabular}

- Periods of forage stocks distribution

The period of distribution (from start to depletion of stocks) of forage stocked is presented in Figure 3 . Overall, crop residues are used from January to June. The majority of farmers (54\%) began using their forage stock in March. April is the second period when more farmers distributed crop residues to animals ( $27 \%$ of respondents). Forage stocks are generally depleted during the months of May (46\%) or June (46\%).

\section{Characterization of milk production and its uses on the farms}

Table 4 shows the different parameters related to milk production on the surveyed farms. There is a variation in the average number of cows on the farm and the number of lactating cows in all groups. Group 2 shows higher values for these parameters than group $1(p<0.05)$ and group 3 has intermediate values between the two groups. Thus, 7.14 cows were noted in group 2, 3.7 cows in group 1 and 5.88 cows in group 3 . These numbers of cows represent $31-32 \%$ of the herd size.

The average amount of milk per day and per cow did not differ significantly between groups; it ranged from 0.81 liter in group 3 to 1.19 liters in group 2. 
The farms recorded an average 4.56, 5.35 and 6.51 liters of milk in the wet season against 2.46, 3.0 and 3.78 liters in the dry season respectively in groups 1,3 and 2 , showing a decrease of 46,44 and $42 \%$ in the same direction. Most of this production is self-consumed on the farms, with averages of $3.58,3.92$ and 5.19 liters in the wet season, representing $78 \%, 73 \%$ and $79 \%$ of total production in groups 1, 3 and 2 respectively.

The quantities of milk sold are low and do not differ significantly between groups in either the wet or dry seasons; they represent $24.76 \%$ and $21 \%$ of total production in the wet and dry seasons respectively.

Table 4 : Estimation of the production and the uses of milk on farms

\begin{tabular}{llll} 
Variables & Group 1 & Group 2 & Group 3 \\
\hline Herd size & $11,91 \mathrm{a}$ & $22,19 \mathrm{~b}$ & $18,96 \mathrm{~b}$ \\
\hline Number of cows & $3,70 \mathrm{a}$ & $7,14 \mathrm{~b}$ & $5,88 \mathrm{ab}$ \\
\hline Number of milking cow & $2,12 \mathrm{a}$ & $3,70 \mathrm{~b}$ & $2,96 \mathrm{ab}$ \\
\hline Quantity of milk per cow/day $(\mathrm{I})$ & 0,89 & 1,19 & 0,81 \\
\hline Total milk in rainy season $(\mathrm{I})$ & $4,56 \mathrm{a}$ & $6,51 \mathrm{~b}$ & $5,35 \mathrm{ab}$ \\
\hline Quantity self-consumed in RS* (I) & $3,58 \mathrm{a}$ & $5,19 \mathrm{~b}$ & $3,92 \mathrm{ab}$ \\
\hline Quantity sold in RS $(\mathrm{I})$ & 1,12 & 1,41 & 1,62 \\
\hline Total milk in dry season (I) & $2,46 \mathrm{a}$ & $3,78 \mathrm{~b}$ & $3,00 \mathrm{ab}$ \\
\hline Quantity self-consumed in DS* (I) & $2,07 \mathrm{a}$ & $3,27 \mathrm{~b}$ & $2,31 \mathrm{c}$ \\
\hline Quantity sold en DS $(\mathrm{I})$ & 0,47 & 0,73 & 0,81
\end{tabular}

* : RS = saison pluvieuse, $*$ :DS = saison sèche

$a, b$ : means on the same line with different indices are significantly different at $P \leq 0.05$.

\section{Discussion}

\section{General characteristics of farmers and cattle farms}

The results of this study showed three types of dairy farms in the zone, two of which are male agropastoralists, i.e., $78 \%$ of the population surveyed. This assumes that milk production is now dominated by agropastoralism, even though we are in the Sahelian zone. Dassou et al (2017) also noted a dominance of agropastoralists (68\%) over Fulani herders (32\%) in their study in the Linguère department of Senegal. In our study, the farmers engaged in livestock production only, were mainly women. This result could be explained by the difficulty of access to land for these women. Moreover, this result on the dominance of agropastoralists confirms a transformation of pastoralist societies that are 
becoming increasingly sedentary, due to various constraints they encounter in their activity. This corroborates the observations of CCF (2019), which reports that pastoralists are evolving towards the agropastoral peasant model that integrates agriculture with livestock.

The low proportion of women in the survey population could be explained by the fact that men are involved in the production of milk, while women are more involved in the processing and marketing of milk. Indeed, a study conducted in Kaolack (Senegal) by Dieng et al. (2014) on the socio-economic profile of actors in the local milk value chain, showed that men were more involved in the production sector, while women were in the marketing and processing of milk.

Most farmers (54\%) were illiterate in the present study. These results are similar to those of Dieng et al. (2014), who reported $57.4 \%$ illiteracy. Sanon et al. (2020) also reported $73 \%$ illiteracy in the study on fattening activities in the same zone. This low level of education among respondents would have an impact on farm management and would constitute a barrier to the intensification of milk production and genetic improvement of cattle in the Sahel of Burkina Faso.

The results on membership in a farmer organization (58\%) corroborate those of Zorma (2017) and Sanon et al. (2014), who reported $58 \%$ membership in an organization in their studies of fattening activities. This proportion would be an asset to benefit from various support/funding of their activities by some development agencies/projects.

The information on farms shows that the extensive system is dominant ( $85 \%$ of respondents). Indeed, the feeding system consisting of pasture and feed supplements is common in the area, and is one of the characteristics of extensive dairy farming. This supplementation, consisting of crop residues and cottonseed cake, allows to maintain milk production to some extent and prevents undernutrition in the household. The higher level of cottonseed cake intake in Group 2 could be explained by the larger herd size in this group and/or the purchasing power of farmers; it could be explained also by the fact that the farmers in this group are aware of the importance of this supplementation in the management of their animals.

In the Sahel, and in extensive farming in general, the cattle herd does not have a habitat per se, which explains the results observed. The animals lie down on the outskirts of the concessions; these areas constitute the farmers' home fields and are fertilized by organic manure throughout the dry season. The cattle herd is generally driven away from the farms in the wet season and returns after the harvest. Only the core herd remains and is supervised by children who drive it to pasture daily.

Crop residues are an important feed resource in the Sahelian zone. Thus, all farmers use these resources to feed their animals. This represents a real factor in the integration of crop and livestock productions, insofar as animal manure is also used to fertilize the fields.

However, there is a lack of appropriate infrastructure for storage, which remains a limiting factor for improving production. Indeed, the majority of farmers (88\%) stored the fodder in various locations that do 
not allow preserve the nutritional value of the fodder. Yet, proper storage of these forages could improve the production capacity of animals (Hanzen et al., 2013). The result on sheds (65\%) corroborates those of Lawal et al. (2017), who reported that the storage mode on sheds is the most practiced in the urban community of Niamey. Only Group 2 records a relatively appreciable rate of farmers who own a hayloft (24.32\%). This infrastructure is of capital importance for preserving the nutritional value of fodder and ensuring adequate animal feed. However, the cost of construction remains a limiting factor for the adoption of this technology. Thus, some farmers, aware of the need to conserve their forages, keep them in unused granaries. The development of a less expensive and therefore more accessible means of fodder conservation is essential for small-scale farmers.

\section{Use of crop residues}

With respect to the use of crop residues, we note that the technique of physical treatment (chopping or cutting) is fairly well known to farmers in groups 1 (57.89\%) and 3 (53.85\%) who applied this technique to roughage before distributing it to the animals. This result is very interesting, because it improves the use of these feeds by the animals. Indeed, studies have shown that chopping improves straw intake by about 20\% (Rokbani and Nefzaoui, 1995). Better adoption by farmers of this roughage processing technique, would allow better use of crop residues and could thus contribute to solving the livestock feed deficit in the Sahelian zone of Burkina Faso. In addition, the processing of fodder to reduce the bulky volume by techniques such as grinding, granulation could give more value, while facilitating the conservation in the bags.

The length of the period of use of crop residues would be correlated with the availability of natural fodder on pasture. Indeed, Sanon et al. (2015) noted a reduction rate in pasture herbaceous biomass of $76-85 \%$ as early as January compared to the optimum recorded in September-October. Furthermore, crop residues distributed early to animals from January, would be intended for dairy cows to maintain milk production and milking (Coulibaly et al., 2007), and thus improve the production capacity of dairy cows (Hanzen et al., 2013).

\section{Milk production and its uses on the farms}

The average amount of milk per cow ( 0.81 to 1.19 liters depending on the group) is within the range of 0.71 and 1.57 liters obtained by Diao et al. (2002) in the peri-urban area of Kolda, Senegal, with or without dry season supplementation. The value of 1.19 liters obtained with group 2 is similar to the value (1.14 liters) noted by Gbenou et al. (2020) on crossbred cows (Gir x Borgou) fed on Panicum maximum pasture. For all groups, the quantities obtained are lower than the results obtained by Sissao et al. (2016) with two (1.7 liters) and three (3.2 liters) milking per day. These differences could be explained by the rearing conditions, particularly the level of feed supplementation provided to the cows, as the Zebu breed used was the same. It should be noted that the amount of milk does not take into account the quantity consumed by the calves, and therefore does not reflect the potential production of the cows. In fact, the 
farmer sometimes modulates the withdrawals of cow's milk, so that the calves do not suffer. The rhythm and intensity of milking may depend on the food and/or financial needs of the household. Overall, the decrease in milk quantities in the dry season compared to the wet season can be explained by the decrease in the availability of good quality fodder and water during this period. In fact, in the wet season, the availability of a variety of highly palatable forage species allows an increase in milk production, whereas in the dry season, only the provision of a supplement in the form of concentrated feed allows the maintenance of milk production. Moreover, studies have shown that adequate supplementation could remove the influence of the season on milk production (Hama, 2005 in Kassa et al. (2016)). The production observed in the dry season in our study would be the result of this supplementation, as all the farmers stated that they practiced it. However, the level of this supplementation would be low to induce sufficient production.

The total quantities of milk per farm of 4.56 to 6.5 liters, depending on the group, obtained in the wet season are within the range of 0-10 liters reported by Boukari et al. (2007) for the majority of households in rural Niger.

The very high proportion of milk consumed, $73-78 \%$, would be related to the ethnic group present, the Fulani, whose dietary habits are based on the consumption of milk and derived products. Diop et al (2009) also reported a significant proportion of milk consumed by the Fulani (35.4\%), which is lower than our results. We agree with these authors that the amount of milk used is a function of the ethnic group, marketing opportunities and the amount of milk available from the herd.

In conclusion, this study allowed to distinguish three types of dairy farms in the Sahelian zone of Burkina Faso, dominated by agropastoralism. Thus, crop residues are systematically used to feed the animals, while manure is collected to fertilize the fields. However, the technical level of farmers is low, as most use rudimentary techniques in the areas of fodder conservation, fodder use and manure storage. This would mean that the technologies generated by research in these fields are unknown to farmers. Capacity building through training in various agropastoral fields such as crop residues conservation and treatment and compost production is needed to boost milk production. Supports for the construction of fodder storage infrastructure, and equipment for fodder processing of in order to enhance its value would be of great help.

\section{Declarations}

\section{Acknowledgements}

This study was carried out in the framework of the project "Sustainable intensification through better integration of crop and livestock production systems for improved food security and environmental benefits in Sahelian zone of Burkina Faso", a collaborative research project coordinated by ICRISAT and financed by the Sustainable Intensification Lab (SIIL) of the Feed the Future (FtF) program of USAID, to which to which the authors gratefully acknowledge. 


\section{i. Funding}

The research activities in this paper benefits the finding from USAID through the Feed the Future (FtF) program on Sustainable Intensification Lab (SIIL).

\section{ii. Conflicts of interest/Competing interests}

Not applicable

iii. Ethics approval

The authors declare that the work is original and the manuscript has not been submitted elsewhere to another journal

iv. Consent to participate

Not applicable

v. Consent for publication

Not applicable

vi. Availability of data and material

The datasets generated during and/or analysed during the current study are available from the corresponding author on reasonable request.

vii. Code availability

Not applicable

viii. Authors' contributions

- SHO: contribute to conceived the study, analyse data and write the paper

- NBS: contribute to performed research and to write the paper

- KS: contribute to performed research and to write the paper

- BVMC: supervise the work and read the manuscript

\section{References}

1. Alary, V., Duteurtre, G., Faye, B., 2011. Élevages et sociétés : les rôles multiples de l'élevage dans les pays tropicaux. INRA Prod. Anim., 2011, 24 (1), 145-156. 
2. Boukary, A.R., Chaïbou, M., Marichatou, H., Vias, G., 2007. Caractérisation des systèmes de production laitière et analyse des stratégies de valorisation du lait en milieu rural et périurbain au Niger : cas de la communauté urbaine de Niamey et de la commune rurale de Filingué. Revue Élev. Méd. vét. Pays trop., 2007, 60 (1-4) : 113-120.

3. Camara, A., Dieng, A., Mergeai, G., 2015. Amélioration des systèmes de production mixtes en Afrique soudano-sahélienne. Rôle de l'espèce Stylosanthes hamata (L.) Taub. (Synthèse bibliographique). Biotechnol. Agron. Soc. Environ. 2015 19(3), 281-289.

4. CCF (Coalition contre la faim), 2019. La filière lait local en Afrique de l'Ouest : une filière entrepreneuriale prometteuse. Position paper, septembre 2019. 16p

5. Coulibaly, D., Moulin, C.H., Poccard-Chappuis, R., Morin, G., Sidibé, S.I. et Corniaux, C., 2007. Evolution des stratégies d'alimentation des élevages bovins dans le bassin d'approvisionnement en lait de la ville de Sikasso au Mali. Revue Élev. Méd. vét. Pays trop., 2007, 60 (1-4) : 103-111.

6. CSAO-OCDE / CEDEAO, 2008. Élevage et marché régional au Sahel et en Afrique de l'Ouest : Potentialités et défis. Paris, 182p.

7. Dassou, S.S., Wade, I. et Agbangba, C.E., 2017. Typologie et rentabilité des systèmes de production laitière à Linguère au Sénégal. Int. J. Biol. Chem. Sci. 11(5): 2163-2176, 2017.

8. Diao, M.B., Senghor, C.D., Diao, B., Thys, E., 2002. Production et transformation du lait en région agropastorale au Sénégal : cas de la zone périurbaine de Kolda. Revue Élev. Méd. vét. Pays trop., 2002, 55 (3) : 221-228.

9. Dieng, K., Kalandi, M., Sow, A., Millogo, V., Ouédraogo, G.A., et Sawadogo, G.J., 2014. Profil socioéconomique des acteurs de la chaîne de valeur lait local à Kaolack au Sénégal, EISMV Dakar, RASPA Vol. 12, numéro 3-4.

10. Diop, A.T., Ickowicz, A., Diène, M., Nzimulinda, J.C., 2009. Production laitière dans la zone sylvopastorale du Sénégal : étude des facteurs de variation et modes de gestion par les populations locales. Revue Élev. Méd. vét. Pays trop., 2009, 62 (1) : 39-47

11. DREP/Sahel, 2014. Monographie de la région du sahel, version définitive. Dori, 146 p.

12. FAO. 2019. Le devenir de l'élevage au Burkina Faso. Défis et opportunités face aux incertitudes. Rome. 56 p. Licence: CC BY-NC-SA 3.0 IGO.

13. Gbenou, G.X., Soule, H.A., Akpo, Y., Djenontin, A.J.P., Sidi, H., Babatounde, S., Houinato, M., Mensah, G.A. Performances laitière et économique des vaches métisses (Gir X Borgou) complémentées avec la drèche de sorgho au pâturage à Panicum Maximum $\mathrm{C} 1$ dans de Nord-Benin. Agronomie Africaine 32 (4) : 439 - 447 (2020).

14. Hanzen, C., Rao, A.-S., Theron, L., 2013. Gestion de la reproduction dans les troupeaux bovins laitiers. Rev. Afr. Sante Prod. Anim., 11 (suppl.) : 91-105.

15. Kassa, K.S., Ahounou, S., Dayo, G-K, Salifou, C., Issifou, M.T., Dotché, I., Gandonou, P.S., Yapi-Gnaoré, V., Koutinhouin, B., Mensah, G.A., et Youssao, I.A.K., 2016. Performances de production laitière des races bovines de l'Afrique de l'Ouest. Int. J. Biol. Chem. Sci. 10(5): 2316-2330. 
16. Lawal A.A.M., Chaibou M., Garba M.M., Mani M., Gouro A.S., 2017. Gestion et utilisation des résidus de cultures pour l'alimentation animale en milieu urbain et périurbain : cas de la communauté urbaine de Niamey. Journal of Applied Biosciences 115: 11423-11433.

17. MRAH (Ministère des Ressources Animales et Halieutiques), 2015. Annuaires des statistiques de l'élevage 2014. Ouagadougou, $177 \mathrm{p}$.

18. Rokbani N., Nefzaoui A. Traitement des pailles à l'ammoniac et à l'urée. Effets du traitement et du hachage sur les performances de croissance des agneaux. In : Caja G. (ed.), Djemali M. (ed.), Gabiña D. (ed.), Nefzaoui A. (ed.). L'Elevage ovin en zones arides et semi-arides. Zaragoza: CIHEAM, 1995. p. 65-74 (Cahiers Options Méditerranéennes; n. 6)

19. Sanon H.O., Drabo A., Sangaré M., Kiendrebéogo T., Gomgnibou A., 2014. Caractérisation des pratiques d'embouches bovine et ovine dans l'Ouest du Burkina Faso. Int. J. Biol. Chem. Sci. 8(2): 536-550, April 2014. http://ajol. Info/index.php/ijbcs.

20. SANON O., OUATTARA F., SAVADOGO M., 2015. Seasonal dynamic of pasture production in the Sahelian rangeland of Burkina Faso. Journal of Agriculture and Environment for International Development - JAEID 2015, 109 (1): 123 - 138.

21. Sanon et al; 2020. Sanon Hadja Oumou1*, Zorma Antoine2, Simian Aziz2, Obulbiga M. Ferdinand1, Compaoré Emmanuel, 2020. Analyse des pratiques d'embouche ovine dans deux zones semi-arides du Burkina Faso. Journal of Applied Biosciences 150: 15390 - 15402.

22. SISSAO M., MILLOGO V. et OUEDRAOGO Georges Anicet, 2016. Effet de la fréquence de traite sur la production laitière de la vache Zébu Peulh. Int. J. Biol. Chem. Sci. 10(6): 2555-2567.

23. STaal S., 1995. Peri-urban dairying and public policy in Ethiopia and Kenya. PhD Dissert., University of Florida, Gainesville, FL, USA, 255 p.

24. Zorma A., 2017. Production et valeur alimentaire des résidus de culture de variétés à double objectifs utilisés dans l'alimentation animale dans la région sahélienne du Burkina Faso. Mémoire d'Ingénieur du Développement Rural, option Elevage, Institut du Développement Rural, Université Nazi BONI de Bobo-Dioulasso, Burkina Faso, 88p.

\section{Figures}




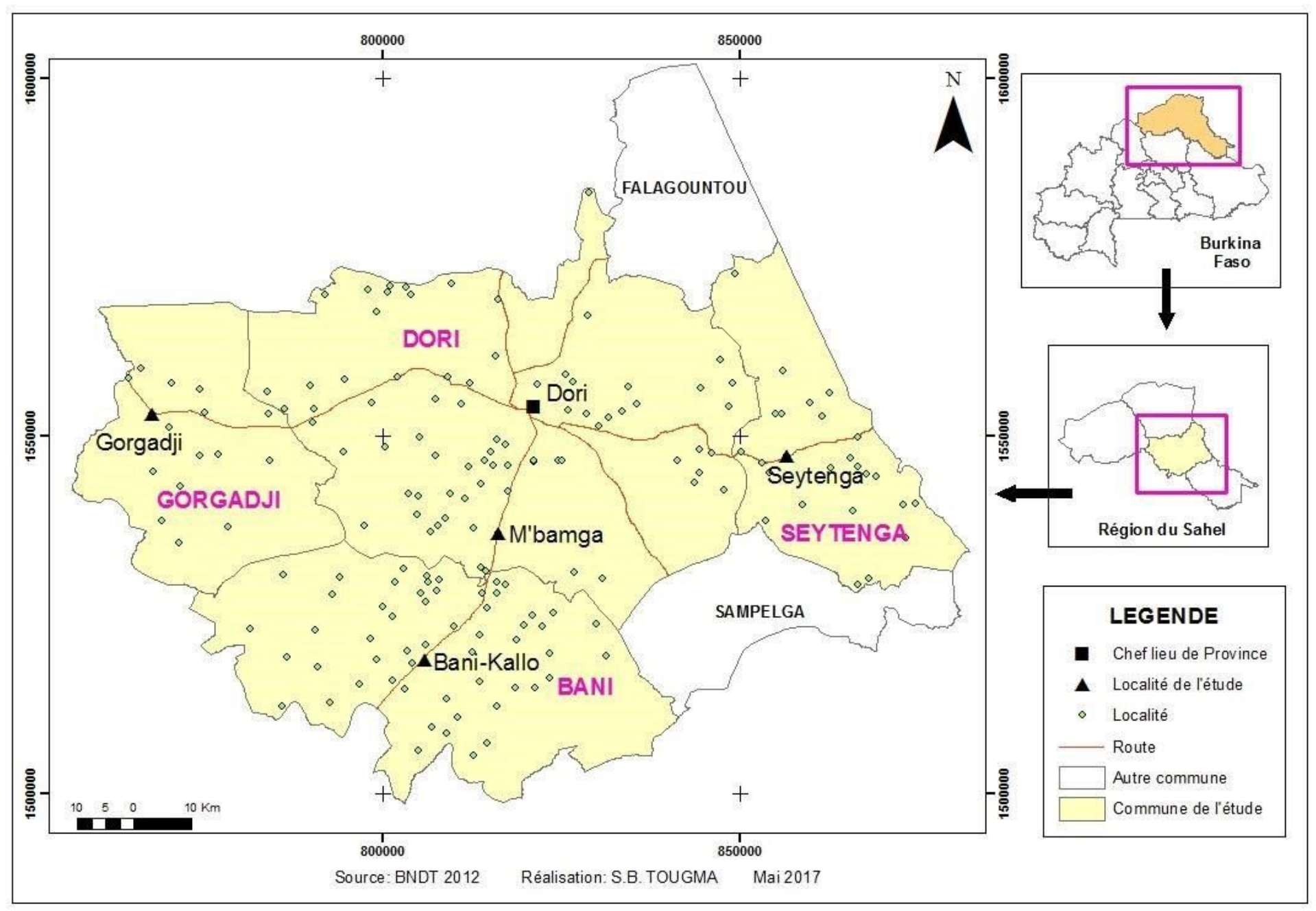

Figure 1

Localisation of the study sites 


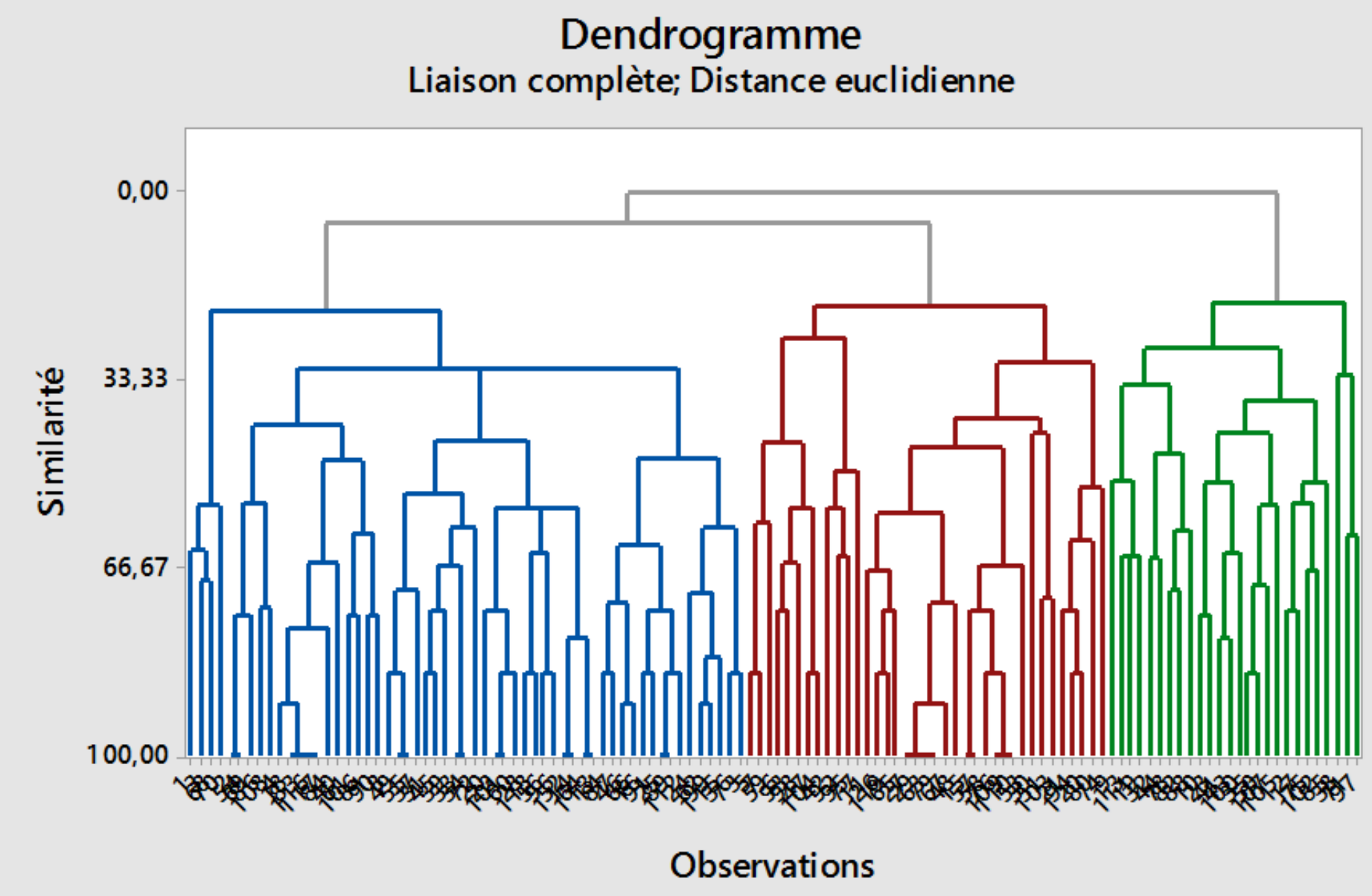

Figure 2

Dendrogram showing the three groups of farmers.

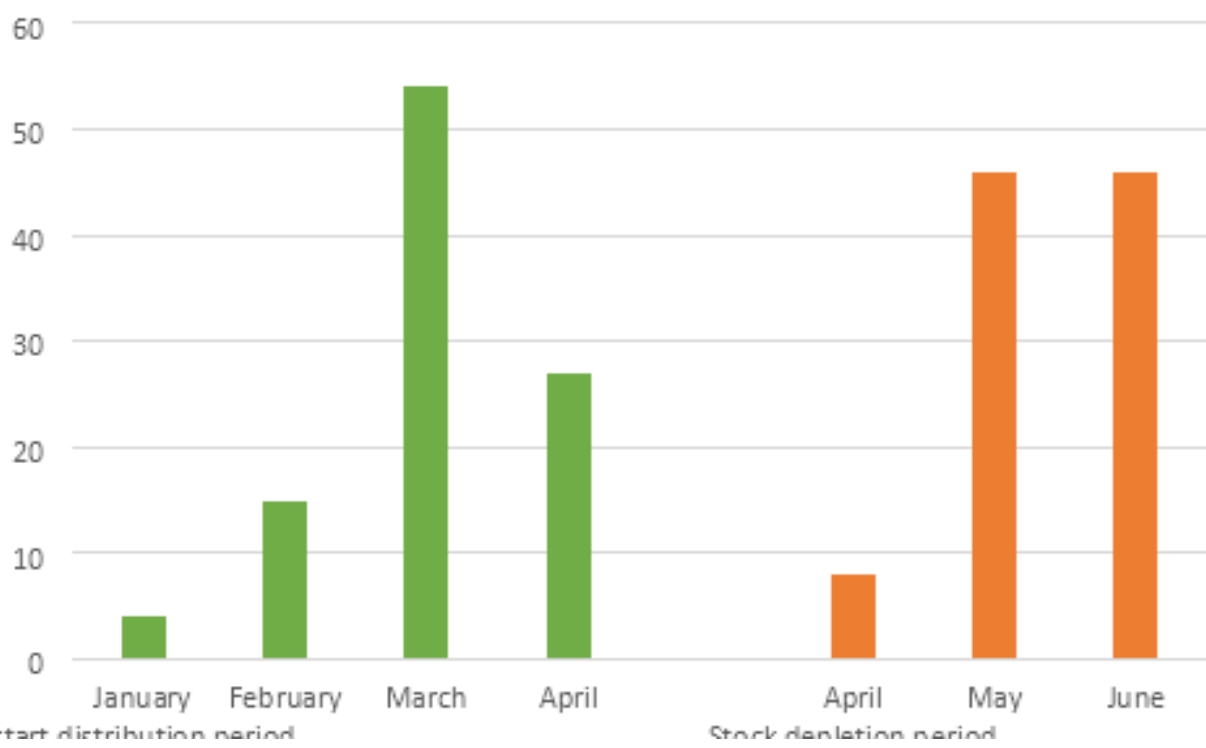

Figure 3

Les périodes début de distribution et fin des stocks fourragers 